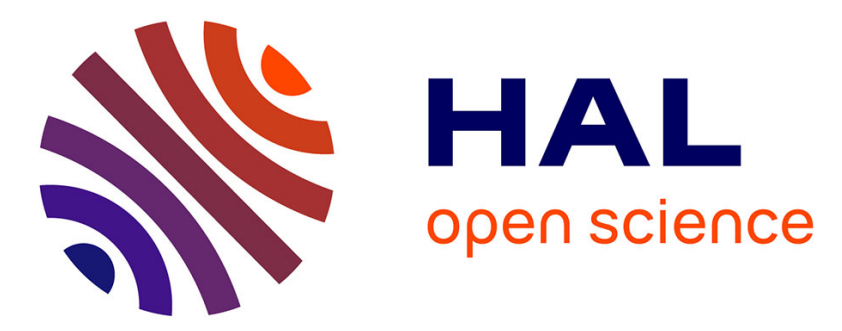

\title{
Influence of Co on the Magnetic and Magneto-Optical Properties of Co-Ni/Pt and Co-Ni/Au Multilayers
}

\author{
R. Krishnan, M. Seddat, M. Porte, M. Tessier, S. Visnovsky, M. Nyvlt
}

\section{To cite this version:}

R. Krishnan, M. Seddat, M. Porte, M. Tessier, S. Visnovsky, et al.. Influence of Co on the Magnetic and Magneto-Optical Properties of Co-Ni/Pt and Co-Ni/Au Multilayers. Journal de Physique IV Proceedings, 1996, 06 (C7), pp.C7-85-C7-88. 10.1051/jp4:1996710 . jpa-00254498

\section{HAL Id: jpa-00254498 https://hal.science/jpa-00254498}

Submitted on 1 Jan 1996

HAL is a multi-disciplinary open access archive for the deposit and dissemination of scientific research documents, whether they are published or not. The documents may come from teaching and research institutions in France or abroad, or from public or private research centers.
L'archive ouverte pluridisciplinaire HAL, est destinée au dépôt et à la diffusion de documents scientifiques de niveau recherche, publiés ou non, émanant des établissements d'enseignement et de recherche français ou étrangers, des laboratoires publics ou privés. 


\title{
Influence of Co on the Magnetic and Magneto-Optical Properties of $\mathrm{Co}-\mathrm{Ni} / \mathrm{Pt}$ and $\mathrm{Co}-\mathrm{Ni} / \mathrm{Au}$ Multilayers
}

\author{
R. Krishnan, M. Seddat, M. Porte, M. Tessier, S. Visnovsky* and M. Nyvlt* \\ Laboratoire de Magnétisme et d'Optique, Bâtiment Fermat, 45 avenue des États-Unis, 78035 Versailles \\ cedex, France \\ * Institute of Physics, Charles University, Ke Karlovu 5, 12116 Prague 2, Czech Republic
}

\begin{abstract}
Résumé : Nous décrivons nos études magnétiques et magnéto-optiques sur des multicouches Co$\mathrm{Ni} / \mathrm{M}(\mathrm{M}=\mathrm{Pt}, \mathrm{Au})$ préparées par évaporation sous ultra vide. $L^{\prime}$ anisotropie de surface $\mathrm{K}_{\mathrm{s}}$ augmente linéairement avec la teneur en Co ce qui vérifie le modèle à un ion. La teneur relative de Ni permet d'ajuster la température de Curie afin de pouvoir utiliser ces matériaux pour l'enregistrement thérmomagnétique. La rotation Kerr présente un pic vers $4 \mathrm{eV}$ pour les multicouches à base de $\mathrm{Pt}$, qui se situe vers $2,5 \mathrm{eV}$ pour celles d'or. On discute des résultats.
\end{abstract}

\section{INTRODUCTION}

Magnetic multilayers are a new class of materials with novel properties. One of the most promising applications of magnetic multilayers (ML) is for magneto-optic (MO) storage media. The typical examples such as $\mathrm{Co} / \mathrm{Pt}$ and $\mathrm{Co} / \mathrm{Pd}$, by virtue of their strong uniaxial anisotropy and good magneto-optical effects, are potential candidates for MO storage applications in the blue light wavelength and hence have attracted much attention from several research groups $[1,2,3]$. New class of materials based on Co-Ni/Pt instead of pure $\mathrm{Co} / \mathrm{Pt}$ have also been suggested recently by some authors and by us as well $[4,5,6]$ which show similar properties as $\mathrm{Co} / \mathrm{Pt}$ but with a relatively lower Curie temperature of the order of $250^{\circ} \mathrm{C}$. Writing at such temperatures is far more safer and will not cause any interfacial diffusion which is of great importance for application. We found that the surface anisotropy $\left(\mathrm{K}_{\mathrm{S}}\right)$ in this system varied linearly with the Co concentration which is of fundamental importance [5]. We therefore wanted to study in detail this aspect and extended our study to $\mathrm{Co}-\mathrm{Ni} / \mathrm{Au}$. We chose the system based on $\mathrm{Au}$ for the following reasons. $\mathrm{Co} / \mathrm{Au}$ has been intensely studied in the past $[7,8]$ and it shows perpendicular anisotropy for thin Co layers. We had shown that in Ni/Au multilayers $\mathrm{K}_{\mathrm{s}}$ is negative [9] and it is therefore interesting to see if the addition of Co would make $\mathrm{K}_{\mathrm{s}}$ positive. We describe in this work the magnetic and the magneto-optical properties of $\left(\mathrm{Co}_{\mathrm{X}} \mathrm{Ni} 1-\mathrm{x}\right) / \mathrm{M},(\mathrm{M}=\mathrm{Pt}, \mathrm{Au})$ multilayers prepared by evaporation.

\section{EXPERIMENTAL DETAILS}

The multilayers were prepared by sequential evaporation using a dual e-beam under ultra high vacuum conditions. The details of the deposition can be found in ref. 2 . For depositing the $\mathrm{Co}_{x} \mathrm{Ni}_{1-\mathrm{x}}$ alloy layers, we first prepared an alloy ingot and used it as a source. Subsequently the composition was determined on a film of $\mathrm{Co}_{x} \mathrm{Ni}_{1-\mathrm{x}}$ about $150 \mathrm{~nm}$ thick. No difference in the composition between the source and the layer could be detected. Both glass and silicon were used as substrates. First Pt, Au buffer layer $100 \AA$ thick was deposited at room temperature and then annealed at $200^{\circ} \mathrm{C}$ for 2 hours. The multilayers were then grown on this buffer layer at room temperature. The $\mathrm{Pt}$, Au layer thickness $\mathrm{t}(\mathrm{Pt}, \mathrm{Au})$ was kept constant at $15 \AA$ and that of Co-Ni varied in the range 4 to $30 \AA$. The growth parameters will be designated as $\{t(\mathrm{Co}, \mathrm{Ni}), t(\mathrm{Pt}$, Au) $\} \times N$ where $N$ stands for the number of bilayers. The top layer was either Pt or Au layer $20 \AA$ thick which also served as a protective layer.

Low and high angle X-ray diffraction studies were made to verify the periodic structure and to calculate the layer thicknesses. Magnetization was measured using a vibrating sample magnetometer (VSM) and the anisotropy was determined by a home made sensitive torque meter. The above properties were measured in the temperature range 6 to $300 \mathrm{~K}$. The $\mathrm{M}-\mathrm{H}$ and magneto-optical loops were also taken at the laser wavelength of $6323 \AA$.. Magneto-optical polar Kerr spectra were studied at $295 \mathrm{~K}$ in the photon energy range from 1.5 to $5.2 \mathrm{eV}$. 


\section{RESULTS AND DISCUSSIONS}

\subsection{Magnetic anisotropy}

Let us first discuss the anisotropy in these multilayers. The effective anisotropy $\mathrm{K}_{\mathrm{eff}}$ in the multilayers can be expressed by the well known phenomenological model by the relation,

$\mathrm{K}_{\text {eff }}=\mathrm{KV}+2 \mathrm{~K}_{s} / \mathrm{t}$, where, $\mathrm{KV}_{\mathrm{V}}$ and $\mathrm{K}_{\mathrm{s}}$ represent the bulk and surface anisotropies and $\mathrm{t}$ the magnetic layer thickness. The term $K_{V}$ contains the contributions from the demagnetization energy $2 \pi \mathrm{M}^{2}$ and the crystalline and magnetoelastic anisotropy energies. Plotting $\mathrm{K}_{\mathrm{eff}} \mathrm{xt}$ as a function of $\mathrm{t}$ yields both $\mathrm{KV}$ and $\mathrm{K}_{\mathrm{s}}$. The results were analysed on the basis of the above model. Fig. 1 shows the variation of $\mathrm{K}_{\mathrm{s}}$ as a function of $\mathrm{Co}(\mathrm{x})$ concentration in $\mathrm{Co}-\mathrm{Ni} / \mathrm{Pt}$ at $5 \mathrm{~K}$.

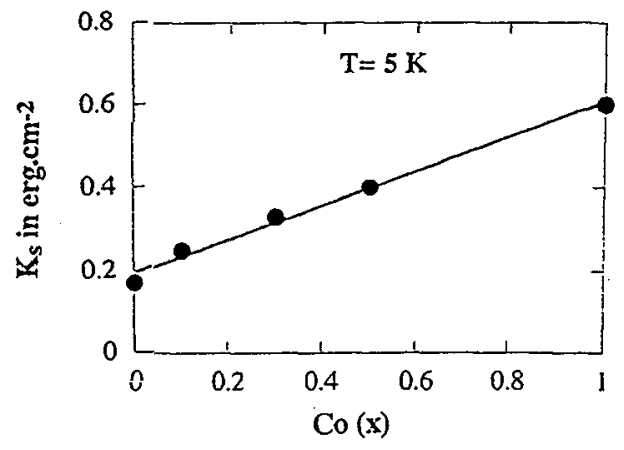

Fig. 1 The variation of $K_{s}$ as a function of $C o$ content in $\mathrm{Co}-\mathrm{Ni} / \mathrm{Pt}$ at $5 \mathrm{~K}$.

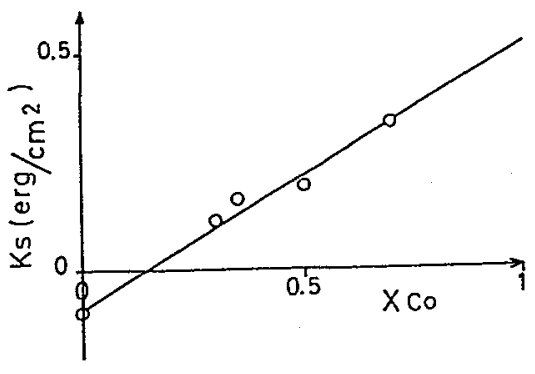

Fig. 2 The variation of $K_{s}$ as a function of Co content in $\mathrm{Co}-\mathrm{Ni} / \mathrm{Au}$ at $5 \mathrm{~K}$.

We discuss the results at $5 \mathrm{~K}$ to eliminate the effects of relatively low $\mathrm{T}_{\mathrm{C}}$ on the properties. The experimental points show the linear variation of $\mathrm{K}_{\mathrm{s}}$ with the Co content. The straight line is calculated based on the relation which assumes the one ion contribution and which can be written as $\mathrm{K}_{s}$ alloy $=\mathrm{K}_{s}{ }^{C o}(\mathrm{x})+$ $\mathrm{K}_{\mathrm{s}} \mathrm{Ni}(1-\mathrm{x})$, where $\mathrm{K}_{\mathrm{s}} \mathrm{Co}$ and $\mathrm{K}_{\mathrm{s}} \mathrm{Ni}$ are surface anisotropy for $\mathrm{Co} / \mathrm{Pt}$ and $\mathrm{Ni} / \mathrm{Pt}$ multilayers and which have been determined by us by studying the respective multilayers. So taking $K_{s} \mathrm{Co}=0.6$ erg.cm and $\mathrm{K}_{s} \mathrm{Ni}=$ $0.17 \mathrm{erg} . \mathrm{cm}^{-2}$ we calculated the straight line in fig. 1 . The excellent agreement confirms our assumption. Fig. 2 shows a similar result for $\mathrm{Co}-\mathrm{Ni} / \mathrm{Au}$ system. It is seen that $\mathrm{K}_{\mathrm{s}}$ which is negative for $\mathrm{x}=0$, starts becoming more and more positive with the addition of Co. The increase in $\mathrm{K}_{\mathrm{s}}$ could be modelled as before. $\mathrm{K}_{\mathrm{s}}$ alloy $=\mathrm{K}_{\mathrm{s}} \mathrm{Co}(\mathrm{x})+\mathrm{K}_{\mathrm{s}} \mathrm{Ni}(1-\mathrm{x})$, where, $\mathrm{K}_{\mathrm{s}} \mathrm{Co}_{\mathrm{and}} \mathrm{K}_{\mathrm{s}} \mathrm{Ni}$ are now surface anisotropies found for Co/Au and $\mathrm{Ni} / \mathrm{Au}$ multilayers. $\mathrm{K}_{s} \mathrm{Ni}=-0.1 \mathrm{erg} . \mathrm{cm}^{-2}$ at $5 \mathrm{~K}$ from our earlier work on $\mathrm{Ni} / \mathrm{Au}[10]$ and $\mathrm{K}_{s} \mathrm{Co}=+0.52$ erg. $\mathrm{cm}^{-2}$ at $295 \mathrm{~K}$ ( $\mathrm{T}_{\mathrm{C}}$ being very high this value is expected to be the same at $5 \mathrm{~K}$ ) from ref. 8 . The straight line in Fig. 2 calculated using the above values explain the experimental points very well. These results also show that the contribution from magneto-elastic effects to $\mathrm{K}_{\mathrm{s}}$ is negligible if not absent. Because the magnetostriction in Co-Ni alloys vary in a complex manner and even changes sign [10], therefore if there is any contribution from this then one can hardly expect a linear variation. So we are led to conclude that the surface anisotropy in these systems arises mainly from crystal field effects (Néel type) and can be treated as single ion anisotropy. It is noteworthy that the modification of the band structure of $\mathrm{Ni}$ by the addition of $\mathrm{Co}$ and vice versa does not seem to influence the contribution of the surface atoms to the anisotropy. More theoretical work in this area would probably be welcome.

\section{2 M.O. loops}

Let us discuss the hysteresis loops taken using polar Kerr rotation at $295 \mathrm{~K}$. With the addition of Co and with decreasing layer thickness, the loops get more and more rectangular and the coercivity also increases. 
Fig. 3 and 4 show a typical loop for the $\mathrm{Co}_{0.3 \mathrm{Ni}} .7 / \mathrm{Pt}$ sample(4.5 $\left.\AA / 15 \AA\right) \times 10$ and $\mathrm{Co}_{0.7} \mathrm{Ni}_{0.3} / \mathrm{Au}$ sample $(5.4 \AA / 15 \AA) \times 16$. However, for the same modulation when the Au buffer layer thickness was increased to $300 \AA$, then the coercivity almost doubled and increased to 800 Oe. Detailed structural studies using X-ray diffraction also showed that the interface quality improved significantly when the buffer layer thickness was increased from 100 to $300 \AA$ [11]. So some optimisation is needed to improve further the loop characteristics. One can nevertheless notice in Fig.3, the rectangularity of the loop for the Pt system, which is interesting for application in information storage.

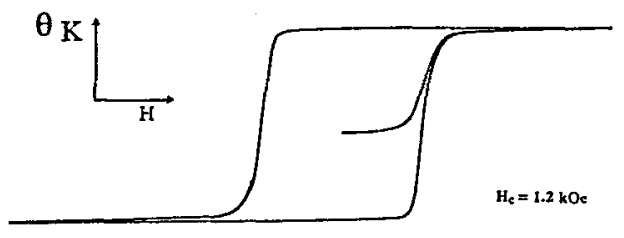

Fig. 3 Kerr loop of $\mathrm{CoO}_{3} \mathrm{Ni}_{0.7} / \mathrm{Pt},(4.5 \AA / 15 \AA) \times 10$.

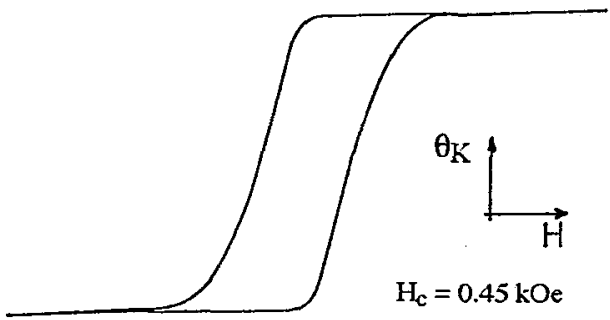

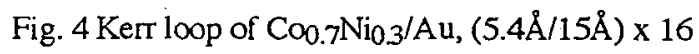

\subsection{Magneto-optical studies}

\subsubsection{Co-Ni/Pt system}

As we have published already on this system we will give only a very brief description here [12]. Fig. 5

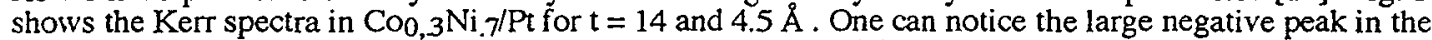
rotation near $4 \mathrm{eV}$. This peak has been attributed to the effect arising from $\mathrm{Co}-\mathrm{Pt}$ interactions in $\mathrm{Co} / \mathrm{Pt}$ and also been observed by us in Ni/Pt [12]. The peak position shifts to lower energy as the Ni concentration increases.

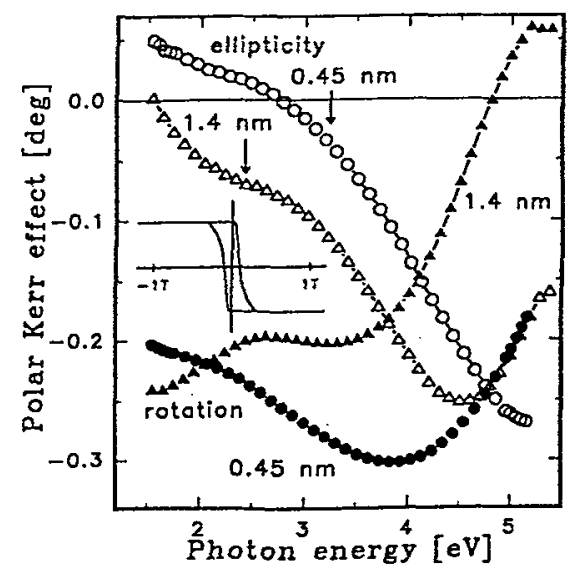

Fig. 5 PKR and PKE spectra in $\mathrm{Co}_{3} \mathrm{Ni}_{0.7} / \mathrm{Pt}$ for $\mathrm{t}=14$ and $4.5 \AA$. Inset $\mathrm{PKR}$ loop for the latter

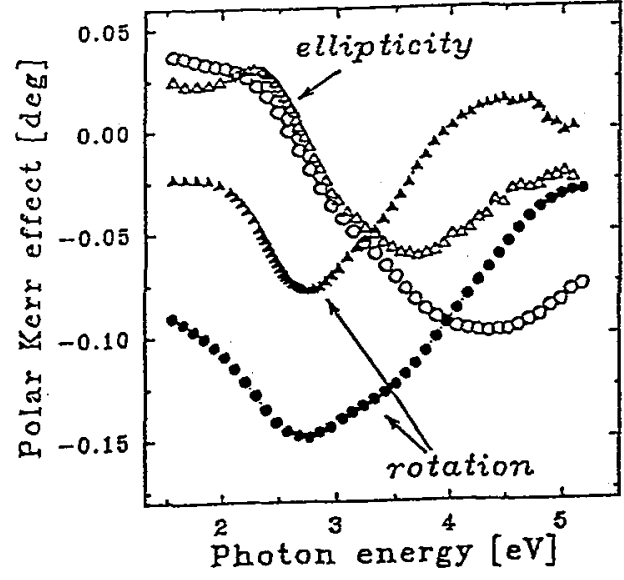

Fig. 6. PKR and PKE spectra in Ni/Au, (6.4/15) X 25 (triangles); $x=0.7(6.4 / 15) \times 16$ (circles)

It is noteworthy that the rotation of $0.28^{\circ}$ at $3 \mathrm{eV}$ (wavelength of interest for high density magneto-optical information storage) of the thinner sample is much higher than that of even $\mathrm{Co} / \mathrm{Pt}$ with similar magnetic layer thickness and furthermore the $\mathrm{T}_{\mathrm{C}}$ is close to $200^{\circ} \mathrm{C}$. All these characteristics make this material a very interesting candidate for application. 


\section{CONCLUSION}

In conclusion, $\mathrm{Co}-\mathrm{Ni} / \mathrm{Pt}, \mathrm{Au}$ multilayers have been prepared by evaporation, their magnetic and magnetooptical spectra studied. The Co concentration dependence of the surface anisotropy can be explained by a single ion model. The Au system sample with $x=0.7$ and $t(\mathrm{Co}-\mathrm{Ni})=5.4 \AA$, shows a rectangular perpendicular loop with coercivity as high as $800 \mathrm{Oe}$ and with polar Kerr rotations close to $0.14^{\circ}$ near 2.8 $\mathrm{eV}$. However in the Pt system the multilayer with $\mathrm{x}=0.3$ and $\mathrm{t}(\mathrm{Co}-\mathrm{Ni})=4.5 \AA$ shows a perfect rectangular loop with $\mathrm{H}_{\mathrm{C}}=1.2 \mathrm{kOe}$, a Kerr rotation of $0.28^{\circ}$ at $3 \mathrm{eV}$ and a $\mathrm{T}_{\mathrm{C}}$ close to $200^{\circ} \mathrm{C}$. These characteristics make this material a potential candidate for magneto-optical storage applications in the blue light. In the MO spectra for thin Co-Ni layers the interband transition of Au can be seen but for thicker layers the behaviour is Co-Ni like. The spectra can be well explained in terms of the model proposed.

\section{REFERENCES}

[1] W.B. Zepper, J.A.M. Greidanus, P.F. Carcia and P.R. Fincher, J. Appl. Phys. 65 (1989) 4971

[2] R. Krishnan, M. Porte and M. Tessier, IEEE Trans. Magn, 26 (1990) 2727

[3] H. Takahashi, S. Fukatsu, S. Tsunashima and S. Uchiyama, J. Magn. Magn. Mater. 93 (1991) 469

[4] M. Mes, J.C. Lodder, T. Takahata, I. Moritani and N. Imamura, J. Magn. Soc. Jpn, 17 Suppl. S1, (1993) 44

[5] R. Krishnan, H. Lassri, M. Seddat, M. Porte and M. Tessier, Appl. Phys. Lett. 64 (1994) 2312

[6] S. Hashimoto, J. Appl. Phys. 75 (1994) 438

[7] C. Chappert and P. Bruno, J. Appl. Phys. 64 (1988) 5736

[8] F.J.A. den Broeder, D. Kuiper, A.P. van de Moesselaer and W. Hoving, Phys. Rev. Let. 60 (1988) 2771

[9] R. Krishnan, H. Lassri, M. Porte, and M. Tessier, IEEE Trans. Magn. 29 (1993) 3388

[10] R.M. Bozorth, Ferromagnetism, van Nostrand Company Inc., New York 1951

[11] D. Rafaja, M. Chladek, V. Valvoda, M. Seddat, H. Lassri and R. Krishnan, To appear in Thin. Sol. Films

[12] R. Krishnan, M. Nyvlt, V. Prosser, M. Seddat, Z. Smetana, M. Tessier, S. Visnovsky, J. Magn; Magn. Mat. 148 (1995) 283

[13] M. Nyvlt, V. Prosser, S. Visnovsky, J. Ferré, D. Renard, R. Krishnan, J. Magn. Magn. Mater. 148 (1995) 287.

[14]. A. Bounouh, P. Beauvillain, C. Chappert, R. Megy, P. Veillet, J. Magn. Magn. Mater. 148 (1995) 273.

[15] R. Krishnan, H. Lassri, M. Nyvlt, V. Prosser, D. Rafaja, V.Valvoda and S. Visnovsky, J. Magn. Magn.

Mat. 148 (1995) 285

[16]. D. E. Aspnes, SPIE Vol. 452 Spectroscopic Characterization Techniques for Semiconductor Technology (1983) 60. 